УДК 130.2:79(793.2)

DOI: https://doi.org/10.31866/2410-1311.34.2018.154064

Бабушка Лариса Дмитрівна

кандидат філософських наук, Національна музична академія України імені П. Чайковського, вул. Архітектора Городечького, 1-3/11, Київ, 02000 https://orcid.org/0000-0001-8563-646X larisababushka@gmail.com

\title{
СЕМІОТИКА КОМУНІКАЦІЇ В ПРАКТИКАХ КОНСТРУЮВАННЯ ФЕСТИВНОЇ КУЛЬТУРИ
}

Мета статті. Виявити специфіку феномену фестивації як особливої семіотичної системи, пов'язаної 3 демонстрацією реалій та символів, що виражають інституалізоване івент-дійство (подію), яке забезпечує повну присутність його учасників до даної царини. Реалізація поставленої мети передбачає розкриття наступних завдань: 3'ясування ролі комунікативних практик як предтечі процесу конструювання нових смислів та інтерпретацій у сучасному фестивному просторі; аналіз семіотичних конструктів та інтегрованих маркетингових комунікацій сучасної фестивної культури, трансформації якої спричинені зростанням знакових структур у взаємодіях різних середовищ. Методологія дослідження передбачає застосування, насамперед, семіотичного, діалектичного, феноменологічного та порівняльного методів, які дозволили обгрунтувати процес сучасного конструювання фестивної культури. Висновки: фестивація в культуротворчому вимірі уможливлює обговорення не лише щодо новітніх технологій, ситуацій трансформації чи образних засобів презентації інформації, а саме про зміну образів буття людини, онтичного як епіцентру комунікативних реалій, який пов'язаний з симулятивним актором, що входить на правах як продуцента, так і реципієнта. Сучасний «гіперфестивний» світ трансформував свято у видовище та шоу-бізнес, з яким Hoтo Festivus нерозривно пов'язаний пуповиною суб'єктно-об'єктних відносин та водночас виступає як вправним режисером, так і активним учасник. Наукова значимість дослідження полягає в узагальненні семіотичних конструктів сучасної фестивної культури, зміни якої спричинені зростанням знакових структур у взаємодіях різних середовищ. Онтологія створення фестивності як такої перетворюється на технологію інформативно-трансформативного дискурсу, де актор чи агент культуротворчості стає суб'єктом дискурсу. Зрештою, всі ці конотації допомагають визначити антропологічні, семіологічні, культурологічні, етичні, естетичні реалії фестивації як глобалізааційного та альтерглобалізаційного проектів.

Ключові слова: фестивація; комунікація; семіотика; знак; образ; глобалізм; альтерглобалізм.

Бабуика Лариса Дмитриевна, кандидат философских наук, Национальной музыкальной академии Украины им. П. Чайковского, ул. Архитектора Городеикого, 1-3/11, Киев

Семиотика коммуникации в практике конструирования фестивной культуры 
Цель статьи. Выявить специфику феномена фестивизации как особой семиотической системы, связанной с демонстрацией реалий и символов, выражающих институализированное ивент-действо (событие), которое обеспечивает полное присутствие участников данной сферы. Реализация поставленной цели предполагает раскрытие следующих задач: выяснение роли коммуникативных практик как предтечи процесса конструирования новых смыслов и интерпретаций в современном фестивизированном пространстве; анализ семиотических конструктов и интегрированных маркетинговых коммуникаций современной фестивизированной культуры, трансформации которой вызваны ростом знаковых структур во взаимодействиях различных сред. Методология исследования предполагает применение прежде семиотического, диалектического, феномено-логического и сравнительного методов, которые позволили обосновать процесс современного конструирования фестивной культуры. Выводы: фестивизация в культуротворческом измерении разрешает говорить не только о новейших технологиях, ситуациях трансформации или образных средствах презентации информации, а именно об изменении образов бытия человека, онтического как эпицентра коммуникативных реалий, связанных с симультанным актером, входит на правах, как продуцента, так и реципиента. современный «гиперфестивний» мир трансформировал праздник в зрелище и шоу-бизнес, с которым Homo Festivus неразрывно связан пуповиной субъектнообъектных отношений и одновременно выступает как умелым режиссером, так и активным участником. Научная значимость исследования заключается в обобщении семиотических конструктов современной фестивной культуры, изменения которой вызванные ростом знаковых структур во взаимодействиях различной среды. Онтология создания фестивности как таковой превращается в технологию информационно-трансформативного дискурса, где актер или агент культуротворчества становится субъектом дискурса. В итоге, все эти коннотации помогают определить антро-пологические, семиологические, культурологические, этические, эстетические реалии фестивизации как глобалистского и альтерглобалистского проектов.

Ключевые слова: фестивизация; коммуникация; семиотика; знак; образ; глобализм; альтерглобализм.

Babushka Larysa, PhD in Philosophical Sciences, Petro Tchaikovsky National Music Academy of Ukraine, 1-3/11, Arkhitektor Horodetskyi St, Kyiv, Ukraine

Semiotics of communication in practices of designing festive culture

The purpose of the article is to identify the specifics of the phenomenon of festivity as a special semiotic system associated with the demonstration of realities and symbols expressing an institutionalized event which ensures the full presence of its participants in this domain. The fulfillment of the abovementioned goal involves completing the following tasks: clarification of the role of communicative practices as a forerunner of the process of constructing new meanings and interpretations in the contemporary festive space; the analysis of semiotic constructs and integrated marketing communications of modern festive culture, whose transformation is caused by the growth of sign structures in the interactions of different environments. 
The research methodology consisted in the use of the semiotic, dialectical, phenomenological and comparative methods, which allowed for substantiating the process of modern design of festive culture. Conclusions. Festivity, in the cultural dimension, makes it possible to discuss not only the latest technology, situations of transformation or figurative means of presenting information but also the change of the images of human existence, the ontical as the epicenter of communicative realities, which is associated with a simulative actor possessing the rights of both the producer and the recipient. The modern "hyperfestive" world has transformed holiday into a spectacle and show business, with which Homo Festivus is inextricably linked by the umbilical cord of subject-object relations while serving both as a skilled director and an active participant. The scientific novelty of the work lies in the generalization of semiotic constructs of modern festive culture, whose changes are caused by the growth of sign structures in the interactions of different environments. The ontology of the creation of festivity as such turns into a technology of informative-transformative discourse, where an actor or agent of cultural development becomes the subject of discourse. As a result, all these connotations help to determine the anthropological, semiotic, cultural, ethical, and aesthetic realities of festivity as globalization and alterglobalization projects.

Key words: festivity; communication; semiotics; sign; image; globalism; alterglobalism.

Вступ. Глобалізаційні та альтерглобалізаційні інтенції, продукуючи планетарну єдність людства, дають виклик життю про необхідність нових підходів щодо творення спільного хронотопу, який унеможливлюється поза переосмисленням наявних механізмів сучасної культури загалом та фестивної (святкової), зокрема. Дослідження актуалізує інтенцію в царині семіотичних процесів, котрі постають важливою частиною нашої реальності, оскільки знаки $\epsilon$ первинними у нашому творенні, з них формуються знакові системи. Упродовж усієї історії людськості формується особлива семіотична реальність як витвір розумової діяльності людини, іiі рукотворності, що існує у вигляді знаків та знакових систем.

Сьогодні майже у всіх прагматично орієнтованих царинах діяльності активно відбувається процес продукування нових семіотичних конструктів, що уможливлює формування інтегративних уявлень у лакунах глобалізму та альтерглобалізму. Мова йде про сучасні комунікаційні івент-індустрії, що продукують ситуації, події, в котрих почасти незначні зміни в повідомленнях, здатні проектувати подальші наслідки для всієї культури, зокрема фестивної. Подібні зміни спричинені зростанням знакових структур у взаємодіях різних середовищ.

Аналіз останніх досліджень i публікацій. 3'ясування аналізу стану опрацювання даної проблематики в науковій літературі засвідчує про фрагментарність та обмеженість розвідок щодо фестивної культури як семіотичної комунікації в умовах глобалізму та альтерглобалізму. Понятійна конструкція «фестивація», «Hото Festivus» (Людина, що святкує) вперше використовувалась сучасним французьким мислителем Ф. Мюре у працях «Після 
iсторії», «Fetivus, Fetivus». Активне використання свята як планового агента соціалізації та інкультурації представлене в працях дослідниці І. Лаврікової, трансгресивного смислу свята у розвідках С. Каштанової, семіотичних конструкціях Н. Лук'янової, постмодерністських рефлексіях Н. Маньковської. Щодо методологічних підгрунть розвідок знаку, якими ми послуговуємося в даному дослідженні, зазначено дві ключові традиції, які концептуально не перетинаються одна 3 одною, але $\epsilon$ протилежними за природою осягнення. 3 одного боку, «діадна» модель знаку Ф. де Соссюра та, «тріадна», 3 іншого, Ч. Пірса, які утримують відмінне розуміння досліджуваного. Останній, підкреслював, що будь-яке розмірковування, мислення має знаковий характер, людина, фактично, за Пірсом, $є$ продуцентом знаків шляхом семіозису, результатом якого постає інтерпретант(а). Дослідження Чарльза Пірса щодо тріадної сутності знаку дозволяє побачити знак у його нескінченній варіативності, виявом чого й слугує сучасна фестивна культура.

Виокремлення невирішених раніше частин загальної проблеми. Одним 3 таких невирішених сегментів дослідження постає аспект виявлення відмінностей семіотичного характеру щодо фестивного та карнавального середовищ, оскільки їх природа така, що самостійно моделює новий хронотоп шляхом зміни знаків («верхівки» - «низами», «раба» - «володарем» тощо). Подібні перетворення символізують підсилення влади хаосу, що виступає предтечею нового творіння, котре знаходить вихід-розрядку саме в святі. На думку А. І. Пігалєва, «подібна карнавалізація завершує справу хаосу і дозволяє зрозуміти нове творіння як диво. Однак диво завжди пов'язане з відмовою і забороною. Ці відмова й заборона не лише передують будь-якому святу, але й постають умовою його можливості» (1998, с. 134-135). Карнавал як вияв святкової народної культури, за звичай, протистоїть культурі державній та церковній. Як зауважував Бахтін, «всі карнавальні форми послідовно позацерковні й позарелігійні. Вони належать до зовсім іншої сфери буття» (1990, с. 11). Карнавальна культура, будучи спадкоємицею римських сатурналій, давньогрецьких діонісійських свят, відрізняється від християнських, насамперед тим, що християнська культура починає набувати диференційно-розмежованого характеру щодо поділу світів на «горний - дольний», «чистий - нечистий», «гріховний - святий» тощо. Апологети християнської культури, вносять коректури щодо розуміння сакрального i профанного світів, де дольне, нечисте, гріховне, себто природне, виводиться 3 царини сакрального (божественного) й піддається профанації. На думку сучасної дослідниці С. Каштанової, «все трансгресивне розташовується в сфері зла і гріховності, але сам механізм трансгресії залишається важливою формою вираження і випробування людиною власної людяності, іiі зв'язку і розбіжності зі світом природи. Якщо, починаючи з архаїки, свята мали релігійний характер, який не відміняв їх трансгресивного, то в християнську епоху святкування поділяються на релігійно-церковні й народні. При цьому вони зберігають свій зв'язок в тому сенсі, в якому розгульне народне свято як трансгресивне «випускання пару» передує церковному святу, супроводжуваному постом і стриманістю <...> $>(2016$, с. 124). 
Отже, виражаючись мовою семіотики, суттю карнавальної культури постає інверсійність офіційної моделі життєустрою, тобто заміна знаків повсякденного світопорядку на «світ на виворіт». Карнавальна свобода постає домінантою, яка підпорядковує усталене життя, уклад власним імпульсам сміхового начала, на відміну від державних і церковних свят, що історично базувались на началах серйозності та офіціозу. В цьому полягає принципова відмінність свята від карнавалу, де останній стирав на певний часовий проміжок усталені, буденні межі існування, які відкривали доступ до природного джерела, в якому «під чарами Діоніса не тільки знову змикається союз людини з людиною: сама відчужена, ворожа або поневолена природа знову святкує свято примирення зі своїм блудним сином - людиною» (Ніцше, 2011, с. 34). Ці свята супроводжувалися низкою трансгресивних первісних ритуалів, за якими, згідно Ф. Ніцше, «ми дійсно на короткі миті стаємо самим Першосущим і відчуваємо його нездоланне жадібне прагнення до життя, його радість буття; боротьба, муки, знищення явищ нам здаються тепер ніби необхідними при цій надмірності незліченних, спраглих до життя і зіткнених в ньому форм існування, при цій переповненій плодючості світової волі» $(2011$, с. 110).

Мета статті. Виявити специфіку феномену фестивації як особливої семіотичної системи, пов'язаної 3 демонстрацією реалій та символів, що виражають інституалізоване івент-дійство, яке забезпечує повну присутність його учасників до цієї царини. Реалізація поставленої мети передбачає розкриття наступних завдань: 3'ясування ролі комунікативних практик як предтечі процесу конструювання нових смислів та інтерпретацій у сучасному фестивному просторі; аналіз семіотичних конструктів та інтегрованих маркетингових комунікацій сучасної фестивної культури, трансформації якої спричинені зростанням знакових структур у взаємодіях різних середовищ.

Виклад основного матеріалу дослідження. Семіотичний простір фестивації постає мейнстрімом сучасного культурного розвитку, оскільки задає тим чи іншим чином аксіологічну та світоглядну інтенції. Презентація та фетишизація престижних речей та послуг, кітчеві агломерації, мода як глемпрезентація образу людини створюють перманентне свято, що не сходить з екрану чи помосту масових сценічних арт-локацій. Знаки як медіатори безпосередньо беруть участь у конструюванні фестивної культури шляхом різноманітних форм комунікацій. А процес конструювання нових смислів відбувається шляхом заміщення та підміни означуваного з референтом знаків, коли наступає відчуття власної причетності щодо самої події й перенесення до заданої символічної реальності як справжньої. Сприятливим помостом щодо відчуття власної причетності, відтак, постає саме фестивний простір, де певна подія (івент) вже перестає сприйматися як дискурс про реальність, а ототожнюючись постає безпосереднім відображенням цієї реальності. Реципієнт отримує задоволення від ототожнення, ефект реальності зміцнює його уявлення про світ, фестивносценічне втілення якого, нерідко відповідає запрограмованим ідеологічним схемам, що виступають у якості природних і універсальних. Підтвердженням даної думки може слугувати еволюція образу, подана Ж. Бодріяром у праці «Симулякри і симуляція» у вигляді його «послідовних фаз: 
- він $€$ відображенням глибокої реальності;

- він маскує і спотворює глибоку реальність;

- він маскує відсутність глибокої реальності;

- він позбавлений зв'язку з будь-якою реальністю;

- він $\epsilon$ чистим симулякром самого себе» $(2004$, с. 12$)$

Симптоматичним постає зауваження дослідниці Н. Маньковської, яка вважала, «якщо в класиці реальність переплавлялась у образ, то зараз образ прикидається реальністю. Проте це водночас і кінець естетизму: мистецтво постає звичайним товаром, предметом консьюмінгу» (2009, с. 278). Доповненням виступає й досить неординарне висловлювання Йосифа Бакштейна щодо «мистецтва як лише примітки чи коментарію на полях макроекномічних битв» (2009, с. 291). Помітно, що інтерес економічної сфери до культури пов'язаний зі зростаючою увагою щодо проблеми споживання, відповідно, розумінням того, що тренди переконливо можна пояснити на прикладі елементарної моделі раціонального споживача, певного осмислення культу споживання як своєрідної драматичної самопрезентації. Так, формат фестивних івентів (Fest-Event) популяризується серед масштабних корпорацій, компаній, які, зазвичай, спроможні відсвяткувати чи відзначити нову прибуткову угоду, дні народження провідних менеджерів або будь-яку іншу подію. Такі Fest-Event покликані, насамперед, підвищити емоційний довіру й лояльність до лобіювання товарубренду. Загалом, так відбувається процес перетворення реальності в універсальний імідж-симулякр як завершальний етап естетизації світу. Так народжується тотальний світ новітнього зразку.

Універсуми буття такі як свято, міф, мова, наука, культура, мистецтво, виступають інструментарієм пізнання та конструювання світу предметів, символічними формами. Трансформація символу до смислу $є$ відтворенням реальності в царині переживання суб'єкта за допомогою символізації світу. Конструювання останнього в символічних формах вирішується проблемою пізнання світу в його мінливості. Однак, символізація, на думку Е. Кассірера, не $\epsilon$ лише «формою духовної адаптації» $(1998$, с. 470). Вона постає проблемою пізнаваності світу, відтак уможливлюе його конструювання за допомогою символічних форм. Беззаперечна заслуга Е. Кассірера (1998) полягає в тому, що він задав принципово нову парадигму розуміння мистецтва в контексті синтезу їх з іншими аспектами людської культури. Авторська інтенція розуміння символу базується на осмисленні того, як народжується той чи інший смисл символу, однак не розкриває розуміння того, що буде підсумком такого осмислення, оскільки смисл символу не даний сам собою, а заданий і розкривається в динаміці його сприйняття як первинної потреби, притаманної людині. С. Лангер (2000), будучи шанувальницею й почасти послідовницею Е. Кассірера (1998), залишалась на дуальних позиціях щодо розуміння символу. 3 одного боку, заперечуючи розуміння символу як апріорної логічної структури, стверджувала, що він $\epsilon$ спонтанним виявленням людської природи. 3 іншого, залишаючись на позиціях підтримки Е. Касіррера (1998), не відкидала думки, що царини людського життя, які перебувають поза межами наукового досвіду, не позбавлені інтелектуального 
характеру й можуть поставати предметом дослідницьких інтересів як філософських, так і культурологічних.

Варто зазначити, що основним ресурсом фестивації $\epsilon$ візуальна репрезентація комунікацій. Точніше, специфікою формування фестивної культури сьогодні постає глобальність мережевої віртуальної комунікації. Теперішні нові образи не передаються за способом зверху до низу, а за мережевим принципом. Візуальний образ виступає ключовим елементом, який визначає раціональність та ірраціональність функціонування комунікативно-візуальних практик. Перевага знакових елементів у комунікативних практиках фестивації, визначається, по-перше, актуалізацією семіотичних форм матеріалу, по-друге, специфікою створення, інтерпретації та обробки візуальних образів різних типів. Подібна модель одночасного застосування раціональності та ірраціональності комунікативних практик, з одного боку, полягає в інтенції на смислову зрозумілість щодо речей в осягненні реальності шляхом звернення до емпіричної фактологічно-доказової бази, а з іншого - до навіювання стійких смислів шляхом інсценування візуальних ефектів при зверненні до ірраціонального боку людини. На думку сучасної дослідниці Н. О. Лук'янової, зміст семіотичних практик конструювання базується на наступних тезах: по-перше, «раціональність комунікативних практик полягає в тому, що вони націлені на раціональне осмислення реальності шляхом звернення до емпіричних фактів та доведенням при визначенні смислової зрозумілості відносно речей»; по-друге, «ірраціональність комунікативних практик виявляється в тому, що вони спрямовані на навіювання стійких смислів за допомогою інсценування візуальних ефектів при зверненні до ірраціональності свідомості людини» $(2016$, с. 168). Посилаючись на праці К.-О. Апеля, сучасний мислитель В. Н. Порус, зауважує наступне: «...учасники комунікації виявляють, що їх смислові каркаси не загальнозначимі, але продовжують «мовну гру», налагоджуючи дискурс, який вміщає різноманітні, але рівноправні системи аргументації <..> прийняти подібне розуміння, за Апелем, означає перейти Рубікон «сцієнтистського об'єктивізму» i визнати, що «людина є водночас i суб'єктом, i об'єктом» соціальних наук, інше кажучи, раціональність підпорядкована цілям і цінностям, що визначаються рішеннями учасників комунікаційних актів» (2008, с. 57-70).

Культура постмодерну підпорядковує вербальний дискурс комунікації візуальному, а останній дедалі радикальніше викликає формати презентації, пов'язані 3 новим піктографізмом, експресивним типом передачі інформації, що утворює своєрідну презентацію тексту, де комунікативна реальність стає активним центром формотворення. Безперечно, глобалізація культурних процесів і комунікації стимулює появу нових дискурсів ідентифікації та нового іміджу спільноти, моделей «реального поза реальністю», себто гіперреальності. Тут «глобалізація сприяє створенню новітньої форми комунікації та інформаційних моделей, а також щільної мережі стосунків, яка пов'язує між собою конкретні групи та культури, трансформуючи динаміку політичних стосунків за межі держави» (Гелд та Мак-Грю 2004). Це, зрештою, не лише впливає на масову культуру, а й віддаляє іiі від Гутенбергівської галактики, за М. Маклюєном, де книга як текстова реальність усувається екранною, а остання, тією чи іншою мірою, створює активний, енергійний засіб ідентичності, де й перетворюється 
на свято тотальної ідентичності. Інтенцією сучасних уявлень щодо культурної ідентичності слугують ідеї транскультурності, мультикультурних впливів не лише на соціальному макрорівні, а й на індивідуальномі макрорівні, які володіють «магнетичним впливом на особистість подібно містичній ініціації» (Маньковская, 2009 , с. 277). Ареною представника сучасного фестивного світу, Homo Festive, постає саме глобалізаційний простір, де він уприсутнюється в статусі агента моделювань ідентичностей. Ним заповнюються екрани, особливо, пов'язані 3 нічним святом, коли кожна ніч перетворюється на перманентне свято, нічна культура усуває культуру дня, а культура дня виглядає буденною i непривабливою. Межі аутентичного мистецтва та стандартної продукції культурної індустрії помітно стираються, де остання, претендує на непропорційно гіпертрофоване місце безперервного включення до фестивного буття. Останнє розраховане на інтерактивістів та інтерартистів. Інше кажучи, посилаючись на Ж. Бодріяра, «коли реальне більше не є тим, чим воно було, ностальгія набуває свого повного значення. Інфляція первісних міфів і знаків реальності. Інфляція вторинної істини, вторинної об'єктивності й автентичності. Ескалація істинного, пережитого, воскресіння образного там, де зникли предмет і субстанція. Шалене виробництво реального та референційного, паралельне й вище щодо шалу виробництва матеріального: такою постає симуляція в сучасній нам фазі стратегією реального, неореального та гіперреального, яку повсюди випереджає стратегія відстрашування» (2004, с. 13).

Тут варто відрізняти дії політичних акцій в фестивному просторі, прагматико-телеологічних за своїм характером, від художніх. Останні, піддаючи сумніву усталену модель, ставлять у глухий кут звичні погляди, окреслюють проблему; а щодо політичних акцій, то тут інша форма взаємовідносин 3 аудиторією. А саме: аудиторія для аукціоніста - це співавтор, вдумливий i критичний співучасник, для політика - противник або прихильник, перформансист грає з аудиторією, політик - на аудиторію, актор - для аудиторії. Мета перформансу - художній образ, політики - влада, актора - переконлива гра.

Так процесуально відбувається формування віртуального холдингу медіа ринку та шоу-бізнесу, стратегій фестивації масової культури, де Homo-Festive в просторі Інтернет технологій утворює самодостатній простір ще нездійсненних можливостей, які можна зазначити як сюрреалізм без підсвідомого. Тобто, надреальність існує, але підсвідоме усувається, заміщується прагматикою та всім комплексом проектування міфів споживання, де фестивація є святом отримання насолоди від символічного споживання інформації. Фактично утворюється та розгорнута риторика цінностей, яка призводить до автоматизованої граматики споживання, де образи, симулякри, символи утворюють ту арт-реальність, яка в контексті соціальної прагматики визначається як рекламні стратегії. Як зазначає У. Еко: «Семіологія візуальної комунікації могла б слугувати трампліном для дослідження таких культурних сфер <..>, у яких візуальні повідомлення водночас постають і предметом користування» (2004, с. 152).

Висновки. Узагальнюючи теоретичне дослідження семіотики комунікації в практиках конструювання фестивної культури, з'ясовано наступне: по-перше, фестивація в культуротворчому вимірі уможливлює обговорення не лише щодо 
новітніх технологій, ситуацій трансформації чи образних засобів презентації інформації, а саме про зміну образів буття людини, онтичне як епіцентр комунікативних реалій, який пов'язаний з симулятивним актором, що входить на правах як продуцента, так i реципієнта. Розуміння віртуального образу використовується в рекламі, що має в собі реалії брендингу, особливо рекламних i пов'язаних 3 PR-інсталяцій, які так чи інакше формують регіональні традиції, національні традиції, що свідчать про альтерглобалістські ініціативи. Інтегровані маркетингові комунікації, зокрема, пов'язані 3 рекламою, модою, дизайном утворюють надзвичайно насичений i рефлективний простір, де осмислюється антропні, семіотичні, візуальні конфігурації культури постмодерну як певні моделі культуротворчості, що абсорбують, адаптують і формують стратегію сприйняття пов'язану з селекцією інформації, а також з сегментуванням, тобто визначенням електорату інформативного цілого, яке підлягає трансформації та передачі.

По-друге, сучасний «гіперфестивний» світ трансформував свято у видовище та шоу-бізнес, з яким Homo Festivus нерозривно пов'язаний пуповиною суб'єктнооб'єктних відносин та водночас виступає як вправним режисером, так і активним учасник. По-третє, онтологія створення фестивності як такої перетворюється на технологію інформативно-трансформативного дискурсу, де актор чи агент культуротворчості стає суб'єктом дискурсу. Зрештою, всі ці конотації допомагають визначити антропологічні, семіологічні, культурологічні, етичні, естетичні реалії фестивації як особливої семіотичної системи, пов'язаної з демонстрацією реалій та символів у глобалізааційному та альтерглобалізаційному просторі.

\section{Список використаних джерел}

1. Бахтин М. М. Творчество Франсуа Рабле и народная культура средневековья и Ренессанса. Москва : Худож. лит., 1990. 543 с.

2. Бодріяр Ж. Симулякри і симулящуія / пер. 3 фр. В. Ховхун. Київ : Основи 2004. 230 c.

3. Гелд Д., Мак-Грю Е. Глобалізаџ̧ія/антиглобалізац̧ія / пер. 3 англ. I. Андрущенко. Київ: К.І.С., 2004. 180 с.

4. Кассирер Э. Избранное. Опыт о человеке / пер. с нем. Б. Вимер и др.; отв. ред. Л. Т. Мильская. Москва : Гардарика, 1998. 779 с.

5. Каштанова С. М. Трансгрессия как социально-философское понятие: дис. ... канд. философ. наук / Санкт-Петерб. гос. ун-т. Санкт-Петербург, 2016. 203 с.

6. Лангер С. Философия в новом ключе: исследование символики разума, ритуала и искусства / пер. с англ. С. П. Евтушенко. Москва : Республика, 2000. 287 c.

7. Лукьянова Н. Д. Сублимация образов и знаков культуры в идеологических стратегиях власти. Человек пожи(р)ающий смысль культуры в д(р)епрессивных трендах циивлизации: коллективная монография. Великий Новгород : Новгородский гос. ун-т им. Ярослава Мудрого, 2016. С. 163-186.

8. Маньковская Н. Б. Феномен постмодернизма. Художественноэстетический ракурс. Москва; Санкт-Петербург : Центр гуманитарных инициатив. Университетская книга, 2009. 495 с. 
9. Ницше Ф. Рождение трагедии из духа музыки: собр. соч. в 5 т. Санкт-Петербург: Азбука, Азбука-Аттикус, 2011. Т.1. С. 34.

10. Культурология XX век: эничклопедия: в 2 m. / А. И. Пигалев. Санкт-Петербург: Алетейя, 1998. Т.2. С. 134-135.

11. Пирс Ч. Логические основания теории знаков / пер. с англ. В. В. Кирюшенко, М. В. Колопотина. Санкт-Петербург : Алетея, 2000. 352 с.

12. Порус В. Н. Рациональная коммуникация как проблема эпистемологии. Эпистемология и философия науки. Москва, 2008. Т. 17. Вип 3. С. 57-70.

13. Эко У. Отсутствуюшая структура: введение в семіологію. Санкт-Петербург : Сипозиум, 2004. 544 с.

14. Muray, P. et Lévy, E. Festivus festivus: Conversations avec Élisabeth Lévy. Paris : Éd. Flammarion, 2008. 485 p.

\section{References}

1. Bakhtin, M. (1990). Tvorchestvo Fransua Rable $i$ narodnaja kul'tura srednevekov'ja i Renessansa [Francois Rabelais' creative work and the folk culture of the Middle Ages and the Renaissance]. Moscow: Khudozhestvennaya literatura.

2. Bodriyar, Zh. (2004). Symuliakry $i$ symuliatsiia. [Simulations and simulation]. Translated from French by V. Khovkhun. Kyiv: Osnovy.

3. Held, D., and Mak-Hriu, E. (2004). Hlobalizatsiia/antyhlobalizatsiia [Globalization/anti-globalization]. Translated from English by I. Andrushchenko. Kyiv: K.I.S.

4. Kassirer, E. (1998). Izbrannoe. Opyt o cheloveke [Selected works. Experience on a person] Translated from German by B. Vimer. Moscow: Gardarika.

5. Kashtanova, S. (2016). Transgressiya kak sotsial'no-filosofskoe ponyatie [Transgression as a socio-philosophical concept]. D.Ed. St. Petersburg State University.

6. Langer, S. (2000). Filosofiya v novom klyuche: issledovanie simvoliki razuma, rituala $i$ iskusstva [Philosophy in a new sense: the study of the symbolism of reason, ritual and art]. Ttranslated from English by S. Evtushenko. Moscow: Respublika.

7. Luk'yanova, N. (2016). Sublimatsiya obrazov i znakov kul'tury v ideologicheskikh strategiyakh vlasti [Sublimation of images and signs of culture in the ideological strategies of power]. Chelovek pozhi(r)ayushchii smysly kul'tury $v$ d(r)epressivnykh trendakh tsivilizatsii: kollektivnaya monografiya. Velikiy Novgorod: Novgorod State University named after Ya. Mudry

8. Man'kovskaya, N. (2009). Fenomen postmodernizma. Khudozhestvennoesteticheskii rakurs [The phenomenon of postmodernism. Artistic and aesthetic perspective]. Moscow; St. Petersburg: Tsentr gumanitarnykh initsiativ. Universitetskaya kniga.

9. Nitsshe, F. (2011). Rozhdenie tragedii iz dukha muzyki: sobr. soch. $v 5$ t. t. 1 , [The birth of tragedy from the spirit of music: a collection of works in 5 vols.vol. 1.]. St. Petersburg: Azbuka, Azbuka-Attikus.

10. Pigalev, A. Ed. (1998). Kul'turologiya XX vek: Entsiklopediya. v 2 t. T.2. [Culturology of the $20^{\text {th }}$ century. Encyclopedia. In vols. 2.vol. 2.]. St. Petersburg: Aleteiya. 
11. Pirs, Ch. (2000). Logicheskie osnovaniya teorii znakov [Logical foundations of the theory of signs]. Translated from English by V. Kiryushenko, M. Kolopotina. St. Petersburg: Aleteiya.

12. Porus, V. (2008). Ratsional'naya kommunikatsiya kak problema epistemologii [Rational communication as a problem of epistemology]. Epistemologiya i filosofiya nauki, T. 17, no. 3. pp. 57-70.

13. Eko, U. (2004). Otsutstvuyushchaya struktura: vvedenie v semiologiyu. [Absent structure: introduction to semiology]. St. Petersburg: Sipozium.

14. Muray, P. et Lévy, E. (2009). Festivus festivus: Conversations avec Élisabeth Lévy. Paris : Éd. Flammarion.

(С Бабушка Л. Д., 2018

Стаття надійила до редакиії: 2.09.2018

\section{УДК 808.5:[378.091.212:341}

DOI: https://doi.org/10.31866/2410-1311.34.2018.154066

Biletska Oksana, Candidate of Cultural Studies, Associate Professor, Kyiv National university of Culture and Arts, 36, Y. Konovaltsia St., 01133 Kyiv, Ukraine, https://orcid.org/0000-0003-1785-9607 bel_o@ukr.net

\section{LANGUAGE CULTURE AS A COMPONENT OF THE INTERNATIONAL RELATIONS SPECIALISTS TRAINING: ORIGINS AND PRESENT}

The purpose of the work is to state the speech culture role in the training of the international sphere of activity specialists as an instrument of interaction with different cultures while performing their professional duties. The methodology of the study is to use such research methods as study, analyses and generalization in order to reveal the notion of speech culture, namely, diplomatic eloquence as the ability to choose and exercise speech act (speech behaviour) depending on the professional speech' goals and content through linguistic means, as well addressing to the strategy and tactics of communication. The scientific novelty is to describe the problem of mastering the diplomatic eloquence skills as an act of a cultural dialogue implementation in the international experts' professional activity. The problems of communication, discourse, and various professional skills formation of specialists from various fields have widely been discussed in the scientific literature, but the problem of diplomatic communication and the speech culture formation skills in the context of professional international activity remains to be studied. Conclusions. Language is not merely a means of diplomatic communication, but rather a tool for expanding diplomatic sphere of activity. Since every language is deeply rooted in a certain culture, it is a unique representation of the world picture. However, the cultural dialogue, implemented through eloquence between different countries, requires the existence of complex multidimensional 